MICHAŁ PIETRZAK (Warszawa)

\title{
Morderstwo w Zachęcie
}

W dniu 16 grudnia 1922 r. prezydent Gabriel Narutowicz uczestniczył $\mathrm{w}$ dorocznej wystawie malarskiej $\mathrm{w}$ gmachu Zachęty. Po otwarciu wystawy prezydent w otoczeniu zaproszonych gości rozpoczął oglądanie wystawionych obrazów. Przed obrazem przedstawiającym budynek Zachęty podszedł do Narutowicza poseł angielski Max Mueller z małżonką i złożył mu gratulacje z powodu wybrania go na prezydenta. Narutowicz odpowiedział, że raczej powinni mu składać kondolencje. W tym momencie padły trzy strzały. Prezydent osunął się na podłogę i w ciągu kilku minut skonał.

Moment zamachu w relacji ówczesnego premiera J. Nowaka wyglądał następująco:

„Szedłem tuż za Narutowiczem... Oglądaliśmy obraz na jednej z krótszych ścian sali i doszliśmy do środka dłuższej ściany, gdy nagle rozległ się suchy trzask, trzech po sobie następujących strzałów. Stałem tuż obok prezydenta Narutowicza i dotykałem go w ścisku lewym ramieniem. Na moment umysł w ogóle nie zdawał sobie sprawy co właściwie zaszło. Dopiero po chwili jak błyskawica zjawiła się myśl: to zamach, przemknęło mi przez głowę, że pewnie na prezydenta, po czym nagle wszczął się zamęt i zamieszanie na Sali. Naokoło blade twarze - jakaś pani łkała. Nie zapomnę nigdy twarzy posła angielskiego Max Muellera, bladej jak płótno... O kilka kroków ujrzałem słusznego mężczyznę, stojącego z wyciągniętą prosto do góry prawą ręką, w której trzymał brauning”.

Człowiekiem tym był Eligiusz Niewiadomski, artysta malarz, współpracownik pism endeckich.

Konstytucja z 17 marca 1921 r. wprowadziła w Polsce ustrój republikański. Władza zwierzchnia w państwie należała do Narodu. Organami Narodu w zakresie władzy ustawodawczej był dwuizbowy parlament, składający się z sejmu i senatu, w zakresie władzy wykonawczej prezydent i rząd. Wymiar sprawiedliwości sprawowały niezawisłe sądy. Parlament pochodził z pięcioprzymiotnikowych wyborów. Jednym $z$ ważnych uprawnień sejmu i senatu połączonych w zgromadzenie narodowe, był wybór prezydenta Rzeczypospo- 
litej. Stosownie do postanowień konstytucji wybory prezydenta powinny być przeprowadzone niezwłocznie po ukonstytuowaniu się sejmu i senatu.

Pierwsze wybory do sejmu i senatu w oparciu o przepisy konstytucji odbyły się: do sejmu 5 listopada 1922 r., a do senatu 12 listopada 1922 r. Spośród 13 milionów osób uprawnionych do uczestnictwa w wyborach sejmowych stanęło do urn wyborczych 8800 000. Wybranych zostało 444 posłów. Układ sił politycznych w sejmie charakteryzował się brakiem wyraźnej większości. Prawica, w skład której wchodziły: Związek Ludowo-Narodowy (pod tą nazwą występowała w sejmie Narodowa Demokracja), Stronnictwo Chrześcijańsko-Narodowe i Chrześcijańska Demokracja, uzyskała około 38\% mandatów, centrowy PSL-Piast i Narodowa Partia Robotnicza 20\%, lewica, do której zaliczono Polską Partię Socjalistyczną PSL-Wyzwolenie 22\%, mniejszości narodowe $20 \%$ mandatów.

Wybory do senatu odbyły się przy niższej frekwencji niż do sejmu. Podział 111 mandatów senatorskich wyglądał podobnie jak w sejmie. Związek LudowoNarodowy uzyskał 29 mandatów, Stronnictwo Chrześcijańsko-Narodowe 11, Chrześcijańska Demokracja 7, PSL-Piast 17, Narodowa Partia Robotnicza 3, PSL-Wyzwolenie 8, Polska Partia Socjalistyczna 7, mniejszości narodowe 27.

Pierwsza czynność nowo wybranych sejmu i senatu, wybory marszałków, przeszła pod znakiem porozumienia stronnictw prawicowych z PSL-Piastem. Na marszałka sejmu został wybrany kandydat PSL-Piast, Maciej Rataj, a marszałka senatu - Wojciech Trąmpczyński, kandydat prawicy. Porozumienie zawarte między stronnictwami prawicy i PSL-Piastem miało jednak krótkotrwały żywot. Rozpadło się wkrótce na skutek niemożności uzgodnienia wspólnej kandydatury na stanowisko prezydenta RP. W tych warunkach ciężar wyborów prezydenta przesunął się z zakulisowych pertraktacji i kombinacji na forum zgromadzenia narodowego.

W dniu 9 grudnia 1922 r. rozpoczęły się obrady zgromadzenia narodowego poświęcone wyborowi prezydenta. Największe szanse miał dotychczasowy naczelnik państwa Józef Piłsudski. Sprzeciwił się on jednak kategorycznie wysunięciu jego kandydatury, motywując swoją decyzję tym, że Konstytucja marcowa nie przyznaje prezydentowi, poza funkcją reprezentacyjną, szerszych uprawnień niezbędnych dla efektywnego piastowania tego stanowiska. Zalecił wybór człowieka, który by miał ciężki chód i lekką rękę.

$\mathrm{Na}$ posiedzeniu zgromadzenia narodowego wszystkie większe ugrupowania polityczne wystąpiły z własnymi kandydatami. Stronnictwa prawicowe zgłosiły kandydaturę M. Zamojskiego, PSL-Piast - S. Wojciechowskiego, PSL-Wyzwolenie - G. Narutowicza, Polska Partia Socjalistyczna - I. Daszyńskiego, mniejszości narodowe - J. Baudoin de Courtenaya. Stosownie do regulaminu obrad zgromadzenia kandydat, który otrzymał bezwzględną większość głosów zostawał prezydentem. W razie gdyby w głosowaniu żaden z kandydatów nie otrzymał wymaganej większości, ten z kandydatów, 
który otrzymał najmniejszą liczbę głosów odpadał z następnego głosowania. Po pierwszym głosowaniu odpadł I. Daszyński, w drugim J. Baudoin de Courtenay, a w trzecim S. Wojciechowski. Pozostało do ostatecznej rozgrywki dwóch kandydatów: M. Zamojski i G. Narutowicz. W ogromnym napięciu przystąpiło zgromadzenie narodowe do ostatecznego głosowania, które miało przynieść definitywne rozstrzygnięcie. Po obliczeniu głosów okazało się, że G. Narutowicz uzyskał 289 głosów, a M. Zamojski 227 głosów. O wyborze G. Narutowicza zadecydowały głosy piastowców. Posłowie i senatorowie PSL-Piast nie mogli oddać swych głosów na kandydata prawicy M. Zamojskiego, największego posiadacza ziemskiego w Polsce, w obawie przed gniewem wyborców chłopskich. Zmuszeni do dokonania wyboru między Zamojskim i Narutowiczem poparli tego ostatniego.

Gabriel Narutowicz urodził się 17 marca 1865 r. w Teleszach na Żmudzi, w rodzinie szlacheckiej, w której żywe były tradycje powstania styczniowego. Szkołę średnią ukończył w Libawie. Wyższe studia rozpoczął na wydziale matematyczno-fizycznym uniwersytetu w Petersburgu, a następnie kontynuował je na politechnice w Zurychu. Po ukończeniu studiów pracował w biurach konstrukcyjnych, zajmujących się budownictwem wodnym. Projektował wiele elektrowni wodnych w krajach Europy Zachodniej. W 1908 r. został powołany na stanowisko kierownika katedry budownictwa wodnego na politechnice w Zurychu. Uzyskał światową sławę jako wybitny specjalista w dziedzinie budownictwa wodnego. W okresie I wojny światowej żywo interesował się sprawą niepodległości Polski. Po jej odzyskaniu zachęcony przez J. Piłsudskiego i W. Grabskiego wrócił do kraju, aby spożytkować swą wiedzę i doświadczenie w odbudowie zniszczeń wojennych. W 1920 r. W. Grabski powołał go na stanowisko ministra robót publicznych w swoim gabinecie. Zachował to stanowisko również w następnych gabinetach utworzonych przez W. Witosa i A. Ponikowskiego. W rządzie A. Śliwińskiego objął stanowisko ministra spraw zagranicznych, które zajmował aż do momentu wybrania go prezydentem.

Wybór G. Narutowicza na stanowisko prezydenta uznała Narodowa Demokracja i sprzymierzone z nią ugrupowania polityczne za dotkliwą porażkę. Reakcja ugrupowań prawicowych na wynik głosowania w zgromadzeniu narodowym była niezwykle gwałtowna. Kampania propagandowa zainicjowana i kierowana przez przywódców prawicy nawiązywała do najgorszych, warcholskich tradycji Polski szlacheckiej. Jej celem było wywarcie presji na G. Narutowiczu, aby stanowiska prezydenta nie przyjął, a gdy to nie odniosło skutku, zmierzała do jego usunięcia przy zastosowaniu wszelkich metod i środków, nie cofając się przed podburzaniem do usunięcia prezydenta przy użyciu siły.

Prasa prawicowa, nadając ton i kierunek tej propagandzie, krytykowała w napastliwy i zjadliwy sposób wybór Narutowicza i atakowała w obraźli- 
wej formie osobę prezydenta. Do znudzenia powtarzanym argumentem był zarzut, że Narutowicza poparły mniejszości narodowe i że większość głosów polskich w zgromadzeniu narodowym poparła kandydaturę M. Zamojskiego. Prasa lewicowa kontrargumentowała, że posłowie i senatorowie mniejszości narodowych mieli te same prawa co posłowie i senatorowie polscy. Argument o większości głosów polskich miał jedynie wartość względną, albowiem 186 głosów polskich posłów i senatorów, która padła na kandydaturę Narutowicza, reprezentowało większą liczbę wyborców aniżeli 227 głosów oddanych na kandydata prawicy M. Zamojskiego.

Publicyści prawicowi atakowali i znieważali prezydenta Narutowicza. Znany polityk i dziennikarz endecki S. Stroński oceniał wybór G. Narutowicza jako

„zdumiewająco bezmyślny, wyzywająco jątrzący, wytwarzający stan rzeczy, z którym większość polska musi walczyć i na podstawie którego żadną miarą nie stanie do pracy państwowej... Naród w którego żyłach płynie krew a nie gnojówka musi się wzburzyć".

Wtórował mu A. Sadzewicz, grożąc lewicy wojną domową:

„Komunikują nam, że jakieś ptasie mózgi urzędnicze biedzą się nad ceremoniałem »objęcia władzy« przez prezydenta Narutowicza. Ma to być połączone z jakimiś festynami publicznymi, paradami ulicznymi itp. Ludność polska prowokacji tej nie zniesie i jeżeli zamiast strumieni krwi, które widzieliśmy na ulicach stolicy onegdaj, popłyną krwi tej rzeki, odpowiedzialność spadnie na puste niestety, ale żywe głowy rozmaitych protokolantów i innych specjalistów od uroczystości i festynów".

W parze z podburzającą propagandą szło organizowanie wieców i demonstracji. Już w dniu wyborów prezydenckich demonstracja zorganizowana przez agitatorów endeckich przeciągnęła ulicami Warszawy, wznosząc wrogie i obelżywe okrzyki przeciwko Narutowiczowi. K. Rudnicki, prokurator Sądu Okręgowego w Warszawie, pisał o tych burzliwych dniach:

„Odbywały się pochody, demonstrowano przed Ministerstwem Spraw Zagranicznych, miejscu urzędowania Narutowicza i przed Bristolem, gdzie mieszkał. Widziałem podniecone grupy ludzkie głoszące hasła antysemickie, uzbrojone w grube laski oddziały korporantów bojowo maszerujące przez Nawy Świat czy Marszałkowską. Miasto wyglądało jak zrewoltowane. Można było oczekiwać jeszcze większych rozruchów. Policja była jednak bezczynna".

W dniu 11 grudnia 1922 r., w którym miało nastąpić zaprzysiężenie nowo wybranego prezydenta demonstracje na ulicach Warszawy przerodziły się 
w krwawe zajścia i rozruchy. Przywódcy prawicy postanowili nie dopuścić do odbycia posiedzenia zgromadzenia narodowego, na którym miało nastąpić zaprzysiężenie prezydenta. Tłumy demonstrantów zorganizowane i zaagitowane przez działaczy endeckich, składające się głównie z obałamuconej młodzieży szkolnej i akademickiej, a także kobiet, starały się nie dopuścić posłów i senatorów lewicowych i mniejszości narodowych oraz G. Narutowicza do gmachu zgromadzenia narodowego. Na placu Trzech Krzyży demonstranci bili posłów lewicowych i żydowskich, legitymowali przedstawicieli dyplomatycznych państw obcych udających się na posiedzenie zgromadzenia. Na wieść o zajściach ulicznych $w$ gmachu sejmu doszło do walki wręcz między posłami lewicy i prawicy. Socjaliści wezwali na pomoc swoje organizacje robotnicze. Na placu Trzech Krzyży miały miejsce walki między bojówkami prawicy i robotnikami. Jeden robotnik został zabity, wielu demonstrantów było rannych. Policja nie interweniowała.

Droga z Belwederu do gmachu zgromadzenia narodowego prowadząca przez aleje Ujazdowskie zapełniona była demonstrantami endeckimi. $\mathrm{Na}$ otwarty powóz, w którym jechał prezydent G. Narutowicz w towarzystwie szefa protokołu dyplomatycznego S. Przeździeckiego, sypały się grudy śniegu, błota, kamienie. Za powozem biegły gromady młodzieży szkolnej, złorzeczącej Narutowiczowi. Wpoprzek alei Ujazdowskich ustawiono barykadę z ławek, którą szwadron ułanów, towarzyszący prezydentowi musiał usunąć. Policja przez cały czas przyglądała się biernie tym zajściom, co jeszcze bardziej rozzuchwalało demonstrantów.

Zaprzysiężenie prezydenta odbyło się przy zachowaniu uroczystego ceremoniału. Wśród członków zgromadzenia narodowego brakowało jedynie posłów i senatorów prawicy, którzy w ten sposób protestowali przeciwko przyjęciu funkcji prezydenta przez Narutowicza. Galeria dla publiczności wypełniona była do ostatniego miejsca. Korpus dyplomatyczny stawił się w komplecie. Gdy G. Narutowicz, poprzedzany przez szefa protokołu dyplomatycznego, wszedł do sali, powitała go burza oklasków. Prezydent stanowczym głosem złożył przysięgę przewidzianą przez Konstytucję marcową.

W dniu 14 grudnia 1922 r. odbyło się w Belwederze przejęcie władzy przez prezydenta Narutowicza od naczelnika państwa Piłsudskiego. Po dokonaniu niezbędnych formalności i odbyciu przewidzianych przez protokół czynności odbyło się śniadanie, w czasie którego Piłsudski, jako ustępujący w Belwederze miejsca Narutowiczowi, wygłosił toast:

„Panie Prezydencie Rzeczypospolitej. Czuję się niezwykle szczęśliwy, że pierwszy w Polsce mam wysoki zaszczyt podejmowania w moim jeszcze domu i w otoczeniu mojej rodziny Pierwszego Obywatela Rzeczypospolitej Polskiej. Panie Prezydencie, jako jedyny oficer polski służby czynnej, który dotąd przed nikim innym nie stawał na baczność, staję oto na baczność przed Polską, którą Ty reprezentujesz". 
Po objęciu władzy rozpoczęły się normalne dni urzędowania prezydenta Narutowicza. Główne wysiłki dotyczyły utworzenia nowego rządu, zdolnego do uspokojenia zaognionych namiętności politycznych. Prasa prawicowa podburzała i jątrzyła w dalszym ciągu. „Gazeta Warszawska”, centralny organ Narodowej Demokracji, domagała się usunięcia zapory, którą był prezydent z łaski obcych, wrogich państwu elementów. Taki sam postulat wysuwał na łamach „Rzeczypospolitej” S. Stroński w artykule Zawada. Prezydent Narutowicz był ciagle niepokojony przez telefon płaskimi dowcipami i ordynarnymi wyzwiskami. W nadsyłanych do kancelarii prezydenta listach grożono mu mordem politycznym, zapowiadano „marną śmierć”, przesyłano arszenik z życzeniami „na zdrowie”.

W dniu 16 grudnia 1922 r. zapora została usunięta. Zabójstwo prezydenta G. Narutowicza przejęło zgrozą cały kraj, wywołując u wszystkich uczciwych ludzi słowa oburzenia i potępienia. Zdawano sobie sprawę, że winę za to co się stało ponosi nie tylko E. Niewiadomski, ale i ci wszyscy, którzy stworzyli atmosferę sprzyjającą dokonaniu morderstwa. Pewni siebie i buńczuczni przywódcy endeccy zrozumieli, że przebrali miarę. Przerażeni zaszłymi wydarzeniami, obawiali się odwetu i zemsty. Starali się też odżegnać od czynu Niewiadomskiego, nazywając go wariatem. Wzburzone masy chłopskie i robotnicze żądały pomszczenia śmierci Narutowicza. Odbywający się w Warszawie w dniu pogrzebu prezydenta samorzutny zjazd działaczy PSLWyzwolenia domagał się zorganizowania marszu chłopów na Warszawę i rozprawienia się z przywódcami endecji. S. Thugutt musiał użyć całego swego autorytetu, jakim się cieszył w Stronnictwie, aby ich odwieść od tego czynu, grożącego wywołaniem wojny domowej. Również wśród warszawskiej organizacji PPS i wśród byłych działaczy POW powstał plan dokonania odwetu na przywódcach prawicy. Akcja odwetowa miała doprowadzić do zastrzelenia kilku działaczy endeckich, najbardziej zaangażowanych w kampanii przeciwko Narutowiczowi. Do realizacji tego planu nie doszło na skutek sprzeciwu I. Daszyńskiego.

Po zabójstwie Narutowicza funkcje prezydenta przejął zgodnie z Konstytucją marcową marszałek sejmu M. Rataj. Przystąpił też niezwłocznie do utworzenia nowego rządu, powierzając stanowisko premiera, stanowczemu w działaniu gen. Władysławowi Sikorskiemu, pełniącemu stanowisko szefa Sztabu Generalnego. Nowy rząd zdecydowanie wystąpił przeciwko podburzającej propagandzie endeckiej i w krótkim czasie przeprowadził pacyfikację nastrojów w kraju. Ponowne wybory prezydenta zakończyły się po raz drugi porażką Narodowej Demokracji. Prezydentem, tymi samymi głosami co Narutowicz, został wybrany S. Wojciechowski. Jeden z posłów lewicy rzucił pod adresem prawicy pytanie: Kiedy go zabijecie?

W dniu pogrzebu G. Narutowicza pogoda dostroiła się do wytworzonej sytuacji. S. Thugutt pisał: 
„Straszny był dzień pogrzebu Narutowicza, pogoda była tak mroczna i mglista, że w samo nawet południe panowały ciemności. Na chodnikach od Belwederu do Zamku stał w gęstym skupieniu jakiś skamieniały w bezruchu, nieodgadniony tłum i nie wiadomo było co się kryje pod tą skorupą milczenia".

Stali ci, co kilka dni temu obrzucali błotem i wyzwiskami Narutowicza. Do nich i do ich przywódców zwracał się ze słowami potępienia Julian Tuwim w znanym wierszu.

Krzyż mieli na piersi, a brauning w kieszeni.

Z Bogiem byli w sojuszu, a z mordercą w pakcie.

Wy, w chichocie zastygli, bladzi, przestraszeni.

Chodźcie głupcy do okien i patrzcie, i patrzcie.

Z Belwederu na Zamek, tętnicą Warszawy.

Alejami, Nowym Światem, Krakowskim Przedmieściem,

Idzie kondukt żałobny, krepowy i krwawy.

Drugi raz Pan Prezydent jest dzisiaj na mieście.

Zimny, sztywny, zakryty chorągwią i kirem,

Jedzie Prezydent - Martwy, a wielki stokrotnie.

Nie odwracajcie oczu. Stać i patrzeć zbiry.

Tak. Za karki was trzeba trzymać przy tym oknie.

Przez serce swe na wylot pogrzebem przeszyte,

Jak jego pierś kulami - niech widzi stolica.

Twarze wasze zbrodniarze - i niech was przywita,

Strasznym krzykiem milczenia, żałobna ulica.

Aresztowany na miejscu zabójstwa E. Niewiadomski udzielał w śledztwie skąpych wyjaśnień odnośnie do motywów swego czynu. Dopiero podczas rozprawy w dniu 30 grudnia 1922 r. wygłosił do zgromadzonej publiczności pełną egzaltacji mowę polityczną. Strzały, od których poniósł śmierć G. Narutowicz, przeznaczył pierwotnie dla J. Piłsudskiego. „Wszystko było gotowe mówił Niewiadomski - przeżułem, przemyślałem wszystko. Wypróbowałem po raz setny rękę i rewolwer, ostatni raz w poniedziałek wieczór; że Piłsudski zginie, byłem tego tak pewny jak tego, że tutaj stoję". Z zamiaru tego zrezygnował, gdy Piłsudski odmówił kandydowania na stanowisko prezydenta. Do Narutowicza nie miał żadnych osobistych uprzedzeń ani pretensji. Strzelał do niego jako do symbolu wytworzonej sytuacji politycznej. Z hamowaną wściekłością i oburzeniem na to, co się w Polsce dzieje, wypowiadał swoje credo polityczne. Ustroju demokracji parlamentarnej głęboko nienawidził. Oskarżał i potępiał socjalistów, ludowców, Piłsudskiego za to, że stworzyli w Polsce ustrój demokratyczny, w którym władza została oddana „,w ręce fornali i pastuchów bydła”. Pasował się na „bohatera narodowego” ratującego ginącą Polskę, zmywającego z jej oblicza „hańbę” wyrządzoną jej przez wybór Narutowicza na prezydenta. 
Po zakończeniu krótkotrwałego postępowania dowodowego zabrał głos oskarżyciel publiczny K. Rudnicki. W swej mowie oskarżycielskiej polemizował szeroko z wynurzeniami Niewiadomskiego. Zobowiązany przez ministra sprawiedliwości W. Makowskiego, nie mógł ukazać tła sprawy ani odsłonić moralnych wspólników mordercy. Mówił jedynie o plugastwach i insynuacjach prasy endeckiej, które Niewiadomski brał na serio. Myślał, że słucha tętna życia narodowego, że dociera do niego głos duszy polskiej, gdy tymczasem słyszał jedynie zatrute jadem nienawiści syki gadzinowe.

Sąd Okręgowy po krótkiej naradzie uznał E. Niewiadomskiego za winnego zabójstwa osoby piastującej najwyższą władzę w państwie i skazał go na karę śmierci. 28 stycznia 1923 r. wyrok się uprawomocnił, gdyż Niewiadomski nie zgodził się na wniesienie apelacji. Z urzędu akta jego sprawy zostały przesłane prezydentowi S. Wojciechowskiemu, któremu przysługiwało prawo złagodzenia kary. Na aktach sprawy prezydent zrobił własnoręczną adnotację następującej treści: „Ani w aktach sprawy, ani w sumieniu nie znajduję podstaw do zmiany wyroku". Następnego dnia o świcie E. Niewiadomski został rozstrzelany na stokach warszawskiej Cytadeli.

Rozstrzelanie E. Niewiadomskiego nie było ostatecznym epilogiem sprawy zabójstwa prezydenta G. Narutowicza. Narodowa Demokracja pragnęła wykorzystać jego śmierć jako atut propagandowy w swej działalności. Od chwili wykonania wyroku rozpoczęła się gloryfikacja osoby Niewiadomskiego. ,Już w noc przed egzekucją - pisał K. Rudnicki - przerwano o godz. 12 wszelkie bale publiczne w Warszawie na znak »żałoby« narodowej, a nazajutrz rozpoczęła się seria nabożeństw żałobnych za »męczennika narodowego «". $\mathrm{Z}$ ambon sławiono Niewiadomskiego jako bohatera narodowego. Zaciekłość polityczna osiągnęła taki stopień natężenia, że nie wahano się nikczemności nazywać cnotą, podłości zasługą, ohydy szlachetnością.

O Narutowiczu tak pisał J. Piłsudski:

„Zgasł. Gdym przyszedł do Belwederu pożegnać się z przyjacielem przygotowanym już do grobu i usiadłem w sąsiednim pokoju, myślałem o przebiegu życia śp. Narutowicza.

Gdzieś, w dworze żmudzkim panowała popowstaniowa żałoba, cichą skargę matki zamiast wesołej piosenki miałeś nad kołyską, gdy ojciec chmurny trwożliwie nasłuchiwał dźwięku dzwonka w oddali, zwiastującego przybycie jakiejś władzy zaborczej. A potem ciche, rzewne lecz uporczywe nauki rodziców - żyj, cierp, kochaj i pracuj. Uczono cię pokory, pokory nieszczęścia. Szeptano ci na ucho wspomnienia walk ubiegłych, pokazywano zatajone gdzieś zakazane obrazki. A potem?

A potem? Powędrowałeś w świat daleki. Nie zaznałeś z nami ani walk, ani nędzy niewoli. W walce nie pozbyłeś się sentymentalizmu swego dzieciństwa, w brudzie niewoli nie zbrukałeś duszy, w pokorze nieszczęścia nie pełzałeś jak gad, już nie łudząc despotów. Zakonserwowałeś gdzieś w szałasach szwajcarskich swe 
dziecinne i młode marzenia, swe dziecinne i młode zaufanie do ludzi, do ich dobrej woli. Przyniosłeś ze sobą nakazy matczyne, kochaj, pracuj. Zamiast nakazu »cierp«, przyniosłeś szczęście życia i pracy w wolnej od kajdan Ojczyźnie.

Zginąłeś od kuli nie wrażej, o której może w dzieciństwie marzyłeś, ale od kuli rodaków, do których niosłeś swą ewangelię miłości i pracy...”. 